\title{
1 Rational engineering of an erythropoietin fusion protein to treat hypoxia
}

2

3 Jungmin Lee ${ }^{1,2,5}$, Andyna Vernet ${ }^{2}$, Nathalie G. Gruber ${ }^{1,2,4}$, Kasia M. Kready ${ }^{1}$, Devin R. Burrill ${ }^{1,2}$, Jeffrey C.

4 Way $^{1,2,3,5, *}$ and Pamela A. Silver ${ }^{1,2}$

5

$6 \quad{ }^{1}$ Department of Systems Biology, Harvard Medical School, Boston, MA 02115, USA.

$7 \quad{ }^{2}$ Wyss Institute for Biologically Inspired Engineering, Harvard University, Boston, MA 02115, USA.

$8{ }^{3}$ Laboratory of Systems Pharmacology, Harvard Medical School, Boston, MA 02115, USA.

$9{ }^{4}$ Current address: Institute of Science and Technology Austria, 3400 Klosterneuburg, Austria.

$10{ }^{5}$ These authors contributed equally to this work.

11

12 *To whom correspondence should be addressed.

13 Email: Jeffrey_Way@hms.harvard.edu 


\section{Abstract}

15 Erythropoietin enhances oxygen delivery and reduces hypoxia-induced cell death, but its pro-thrombotic

16 activity is problematic for use of erythropoietin in treating hypoxia. We constructed a fusion protein that

17 stimulates red blood cell production and neuroprotection without triggering platelet production, a marker

18 for thrombosis. The protein consists of an anti-glycophorin A nanobody and an erythropoietin mutant

19 (L108A). The mutation reduces activation of erythropoietin receptor homodimers that induce

20 erythropoiesis and thrombosis, but maintains the tissue-protective signaling. The binding of the nanobody

21 element to glycophorin A rescues homodimeric erythropoietin receptor activation on red blood cell

22 precursors. In a cell proliferation assay, the fusion protein is active at $10^{-14} \mathrm{M}$, allowing an estimate of the

23 number of receptor-ligand complexes needed for signaling. This fusion protein stimulates erythroid cell

24 proliferation in vitro and in mice, and shows neuroprotective activity in vitro. Our erythropoietin fusion

25 protein presents a novel molecule for treating hypoxia.

26

27 Key words: CD131, erythropoietin, glycophorin A, hypoxia, tissue protection 


\section{Introduction}

Erythropoietin (EPO) stimulates red blood cell (RBC) production in response to hypoxia. It inhibits apoptosis of late-stage erythroid precursors (e.g. CFU-E, BFU-E) and promotes their proliferation and maturation into the fully committed erythroid lineage. Healthy human adult kidneys constitutively produce EPO at low levels, maintaining $\sim 1-5$ pM of circulating EPO under normoxic conditions to sustain constant hemoglobin levels (Elliott et al., 2014). In response to hypoxic stress or massive blood loss, EPO production is stimulated and the number of circulating erythrocytes increases, allowing for more efficient tissue oxygenation (Ghezzi and Brines, 2004).

EPO, like other cytokines and hormones, is pleiotropic and performs several other biological functions in addition to hematopoiesis. Functional EPO receptors (EPORs) are expressed in many tissues other than erythroid precursors, such as endothelial cells, cardiomyocytes, and cells of the central nervous system (Masuda et al., 1994; Ogunshola and Bogdanova, 2013; Hernandez et al., 2017). Deletion of EPORs in mouse embryos results not only in impaired erythropoiesis, but also in developmental defects in the heart, the vasculature, and the brain (Ogunshola and Bogdanova, 2013). Existence of functional EPORs in non-hematopoietic tissues suggests that EPO activates EPORs in different contexts to induce biological activities that are independent of erythropoiesis.

Non-hematopoietic functions of EPO include enhancement of blood clotting and tissue protection in response to hypoxia. These functions suggest that EPO mediates the body's response to hemorrhage, rather than simply being an RBC-producing hormone. When an animal is wounded, the immediate response by the body should be to stop bleeding, increase RBC production, promote tissue oxygenation and ensure tissue survival until oxygen levels return to baseline. Pro-thrombotic effects have been observed as adverse side effects of EPO in the treatment of anemia. Chronic kidney failure patients receiving EPO exhibit higher incidences of strokes, hypertension and death (Drueke et al., 2006; Singh et al., 2006; Pfeffer et al., 2009). Cancer patients treated with EPO had accelerated tumor growth and lower survival rate, possibly due to EPORs on cancer cells themselves, increased tumor angiogenesis, and deep vein thrombosis (Henke et al., 2003; Okazaki et al., 2008; Yasuda et al., 2003). EPO's tissueprotective effects in response to hypoxia have also been shown in animal models and are suggested in several clinical studies (Ehrenreich et al., 2002; Ehrenreich et al., 2007; Aloizos et al., 2015). Intravenous injections of high doses of EPO significantly reduced infarct size and serum markers of brain damage in acute ischemic stroke patients (Ehrenreich et al., 2002), and improved motor and cognitive function in multiple sclerosis patients (Ehrenreich et al., 2007). EPO treatment also resulted in a lower mortality rate and improved neurological recovery amongst traumatic brain injury (TBI) patients (Aloizos et al., 2015).

60 The protective activity of EPO is general to all cellular insults tested so far, including hypoxia, TBI and 61 neuronal excitotoxicity (Fantacci et al., 2006; Robinson et al., 2018; Park et al., 2011).

62 Due to its erythropoietic and tissue-protective functions, EPO holds great promise as a 63 therapeutic for various conditions that cause hypoxia, such as chronic obstructive pulmonary disease 64 (COPD), right-side heart failure and viral infection that requires use of a ventilator. However, two major 
challenges have limited the clinical use of EPO for tissue protection resulting from hypoxia. First, EPO has a pro-thrombotic effect that is observed at low doses, while the tissue-protective effect requires much higher doses. Thus, doses at which EPO might be effective for tissue protection are considered unsafe. Second, EPO (30.4 kDa) has a short plasma half-life of $\sim 8$ hours after a single intravenous injection in humans (Bunn, 2013). Its poor pharmacokinetic profile necessitates frequent dosing to maintain the high levels of EPO required for efficacy.

EPO acts through two distinct receptor complexes (Fig. 1A and B). RBC production and clotting is mediated via EPOR homodimers, whereas the angiogenic and tissue-protective activities of EPO are thought to be regulated by heterodimers of EPOR and the co-receptor CD131 (also known as the receptor common beta subunit) (Hanazono et al., 1995; Brines et al., 2004; Leist et al., 2004; Bennis et al., 2012). EPO monomers bind to EPOR homodimers through a strong interaction $\left(K_{D}=1 \mathrm{nM}\right)$ on one face involving residues such as N147 and R150 (the 'strong face') (Fig. 1A, C and D), and through a weak interaction $\left(K_{D}=1 \mu \mathrm{M}\right)$ on another face involving residues such as S100, R103, S104 and L108 (the 'weak face') (Fig. 1A, C and E) (Elliott et al., 1997; Syed et al., 1998). Tissue-protective signaling through putative EPOR-CD131 heterodimers is thought to involve EPO binding to EPOR through its strong face and an interaction through CD131 that is not well understood (Fig. 1B). This configuration is inferred by the fact that while weak-face mutations (e.g. S100E and R103E) disrupt EPOR homodimer signaling (Leist et al., 2004; Elliott et al., 1997) and RBC production, there is essentially no effect on neuroprotective signaling (Gan et al., 2012). Specifically, Gan et al. (2012) introduced nine mutations on the weak face of EPO, and found that all such mutant proteins mediated neuroprotection - i.e. none of the mutations disrupted a possible interaction with CD131. Thus, it appears that the weak face of EPO can be arbitrarily manipulated for protein engineering purposes and still maintain its tissue-protective function.

We previously constructed 'chimeric activator' proteins in which a mutated EPO with lower receptor affinity is fused to an antibody element that binds to glycophorin A (GPA) (Taylor et al., 2010;

90 Burrill et al., 2016; Lee et al., 2020). Burrill et al. (2016) demonstrated that a weakened form of EPO with

91 a mutation in the strong face (R150A) that is also fused to an anti-GPA antibody element can specifically

92 activate production of RBCs and not platelets. Lee et al. (2020) demonstrated that such an anti-

93 GPA/EPO(mutant) fusion protein can specifically activate RBC formation without stimulation of blood 94 clotting, provided that the fusion protein cannot mediate adhesion of cells bearing GPA (e.g. RBCs) and

95 other cells bearing EPORs. The results of Lee et al. (2020) also showed a correlation between stimulation

96 of platelet production and stimulation of thrombosis, indicating that enhancement of platelet formation

97 could be used as a surrogate marker for EPO-induced thrombosis in these studies. The mutations used in 98 those studies affected the strong face of EPO and those fusion proteins are therefore expected to affect

99 formation of EPOR homodimers and EPOR-CD131 heterodimers. These engineered molecules stimulate $100 \mathrm{RBC}$ formation without activating thrombosis or tissue-protective activity. The present work describes the 

stimulating platelet formation, a surrogate marker of the pro-thrombotic side effect of EPO.

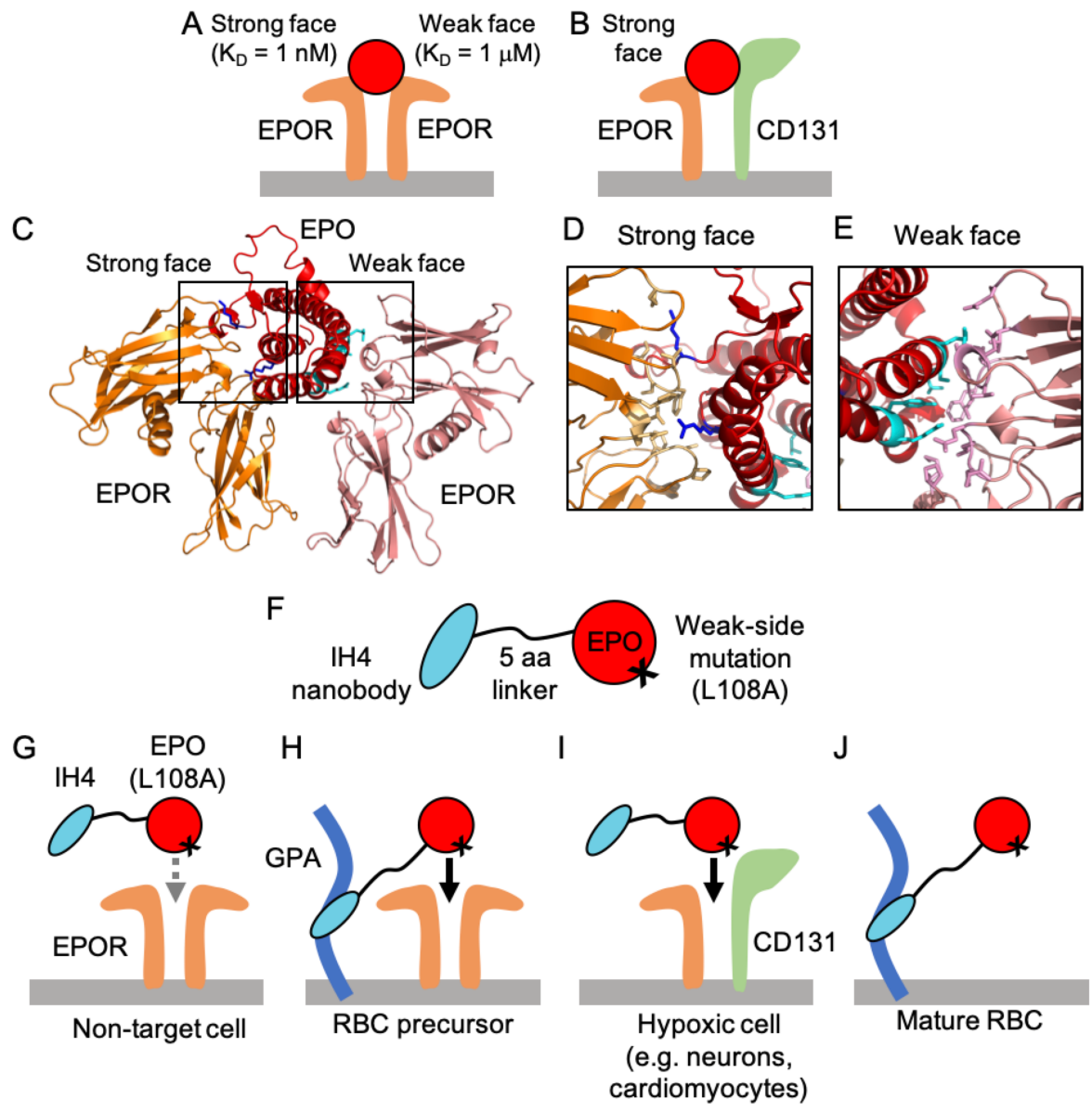

Fig. 1. Design rationale for EPO-H fusion protein. (A-E) Protein interactions of natural EPO with homodimeric EPOR and heterodimeric EPOR-CD131. (A) EPO binds asymmetrically to homodimeric EPOR via two distinct binding interfaces: the strong face $\left(K_{D}=1 n M\right)$ and the weak face $\left(K_{D}=1 \mu M\right)$. (B) EPO can also bind to EPOR-CD131 receptors via its strong face. (C) Protein structure of EPO interacting with homodimeric EPOR (PDB ID: 1EER). Zoom-in of the (D) strong and (E) weak binding interfaces. For receptor binding and activity, critical EPO residues are shown in (D) blue sticks (top: K45, bottom: R150) and (E) cyan sticks (top to bottom: R103, S104, L108, Y15, R14). EPOR residues that are within $4 \AA$ of these residues are shown in light yellow and pink sticks in (D) and (E), respectively. (F) The EPO-H fusion protein consists of the $\mathrm{IH} 4$ nanobody, which targets GPA-expressing cells, attached to a mutant EPO by a five-amino acid linker. (G) Mutant EPO(L108A) has weakened affinity for homodimeric EPOR, and thus, has little effect on non-target cells that lack GPA. (H) On erythropoietic target cells that express both GPA and EPOR, the binding of IH4 to GPA localizes the fusion protein to the target cell surface and allows activation of homodimeric EPOR. (I) The L108A mutation in the EPO element does not disrupt EPO interaction with CD131. As a result, IH4-EPO(L108A) can induce tissue-protective activity via a heterodimeric EPOR-CD131 receptor complex. (J) IH4-EPO(L108A) also binds to mature RBCs via GPA, thereby extending its plasma half-life. 


\section{Results}

\section{Rational design of EPO fusion proteins to address hypoxia}

Our work aims to improve the pharmacokinetics and therapeutic window of EPO, so to harness both its erythropoietic and tissue-protective effects while avoiding thrombosis. To achieve this goal, we designed EPO fusion proteins (EPO-H; $\mathrm{H}$ for hypoxia) based on the concept of a 'chimeric activator' previously developed (Taylor et al., 2010; Burrill et al., 2016; Lee et al., 2020).

EPO-H consists of the nanobody element IH4, which binds to the target antigen GPA, and a

113 mutated version of EPO, fused via a flexible five-amino acid linker (Fig. 1F). We hypothesized that a

114 mutation in the EPO element could weaken its affinity to homodimeric EPOR, thereby avoiding undesired

115 pro-thrombotic effects triggered by homodimeric EPOR signaling on non-target cells (Fig. 1G). The

116 desired erythropoietic activity is rescued by targeted EPO activity on RBC precursor cells directed by the

117 binding of the antibody element, IH4, to the target antigen, GPA (Fig. 1H). This way, EPO activates

118 homodimeric EPORs only on RBC precursors, mitigating the unwanted thrombotic side effects via non-

119 target cells.

Table I. Table depicting predicted properties of wildtype EPO and engineered EPO-H variants. Predicted properties: RBC production, thrombosis, tissue protection, and expected half-life. "+" = increase, "-" = decrease or no effect.

\begin{tabular}{|c|c|c|c|c|c|c|}
\hline & Mutation & Protein & $\begin{array}{c}\mathrm{RBC} \\
\text { production }\end{array}$ & Thrombosis & $\begin{array}{l}\text { Tissue } \\
\text { protection }\end{array}$ & $\begin{array}{c}\text { Expected } \\
\text { Half-life }\end{array}$ \\
\hline & Wildtype & EPO & + & + & + & Short \\
\hline \multirow{4}{*}{$\begin{array}{l}\text { Strong- } \\
\text { face } \\
\text { mutation }\end{array}$} & \multirow{2}{*}{$\begin{array}{l}\text { R150A } \\
\text { (Leaky) }\end{array}$} & $\mathrm{EPO}(\mathrm{R} 150 \mathrm{~A})$ & - & - & - & Short \\
\hline & & IH4-EPO(R150A) & + & - & - & Extended \\
\hline & \multirow{2}{*}{$\begin{array}{l}\text { K45D } \\
\text { (Tight) }\end{array}$} & $\mathrm{EPO}(\mathrm{K} 45 \mathrm{D})$ & - & - & - & Short \\
\hline & & $\mathrm{IH} 4-\mathrm{EPO}(\mathrm{K} 45 \mathrm{D})$ & - & - & - & Extended \\
\hline \multirow{4}{*}{$\begin{array}{l}\text { Weak- } \\
\text { face } \\
\text { mutation }\end{array}$} & \multirow{2}{*}{$\begin{array}{l}\text { L108A } \\
\text { (Leaky) }\end{array}$} & $\mathrm{EPO}(\mathrm{L} 108 \mathrm{~A})$ & - & - & + & Short \\
\hline & & IH4-EPO(L108A) & + & - & + & Extended \\
\hline & \multirow{2}{*}{$\begin{array}{l}\text { S104I } \\
\text { (Tight) }\end{array}$} & $\mathrm{EPO}(\mathrm{S} 104 \mathrm{I})$ & - & - & + & Short \\
\hline & & $\mathrm{IH} 4-\mathrm{EPO}(\mathrm{S} 104 \mathrm{I})$ & - & - & + & Extended \\
\hline
\end{tabular}

At the same time, it is important to ensure that the same mutation in the EPO element does not

126 disrupt EPO binding to heterodimers of EPOR and the co-receptor CD131 when the tissue-protective

127 activity is desired (Fig. 1I). Several EPO mutants were designed based on previous mutagenesis studies

128 (Elliott et al., 1997; Gan et al., 2012). The predicted behaviors of these EPO mutants, either alone or

129 when fused to an anti-GPA antibody element, are outlined in Table I. As part of the design strategy, we

130 use "leaky mutations" that reduce but do not abolish binding; in practice these are mutations in which an 
131 amino acid with a long side chain is replaced by one with a shorter side chain, so that no steric hindrance

132 results and binding is possible. As controls, we also use "tight mutations" in which a side chain is

133 lengthened or the charge of a side chain is reversed, so that a binding activity would be completely lost

134 due to the specific mutation. Because the binding mode of EPO to EPOR-CD131 is not elucidated, unlike

135 that of EPO to homodimeric EPOR, several single point mutations were made in both of the known EPOR

136 contact regions (strong and weak faces, each with $\mathrm{K}_{\mathrm{D}}$ of $1 \mathrm{nM}$ and $1 \mu \mathrm{M}$, respectively). Two residues on

137 the strong face, K45 and R150, and five residues on the weak face, R14, Y15, R103, S104 and L108,

138 were mutated and tested for targeted erythropoietic and tissue-protective activities (Table II and Fig. S1).

139 EPO-H is also expected to have enhanced pharmacokinetics. Fusing mutated EPO to the $\mathrm{IH} 4$

140 nanobody not only increases the size of the molecule to avoid renal clearance, but it also directs the

141 fusion protein to mature RBCs in circulation, further extending serum half-life (Fig. 1J) (Kontos and

142 Hubbell, 2010; Kontos et al., 2013; Burrill et al., 2016). Through these strategies, we constructed EPO-H

143 fusion proteins that would allow administration of high doses required for tissue protection but avoid

144 thrombosis, thereby achieving prolonged activity in the body and reduced dosing frequency.

Table II. In vitro stimulation of TF-1 cell proliferation by EPO mutants and their fusion to $\mathrm{IH} 4 . \mathrm{N}$ indicates the number of repeat experiments, each containing three replicates. N.D. $=$ Not determined. N.A. $=$ Not active.

\begin{tabular}{|c|c|c|c|c|c|c|c|}
\hline & \multirow[b]{2}{*}{ Protein } & \multicolumn{3}{|c|}{ EPO } & \multicolumn{3}{|c|}{ IH4-EPO } \\
\hline & & $N$ & $\begin{array}{l}\log \left(E C_{50}\right)(M) \\
\quad \pm \text { S.D. }\end{array}$ & $\begin{array}{c}\mathrm{EC}_{50} \text { relative } \\
\text { to epoetin alfa }\end{array}$ & $N$ & $\begin{array}{c}\log \left(E C_{50}\right)(M) \\
\quad \pm \text { S.D. }\end{array}$ & $\begin{array}{c}\mathrm{EC}_{50} \text { relative } \\
\text { to epoetin alfa }\end{array}$ \\
\hline \multirow{2}{*}{ Control } & $\begin{array}{c}\text { Epoetin alfa } \\
\left(\text { Epogen }{ }^{\circledR}\right)\end{array}$ & 21 & $-10.22 \pm 0.32$ & 1 & 0 & N.D. & N.D. \\
\hline & $\begin{array}{c}\text { Darbepoetin } \\
\left(\text { Aranesp }^{\circledR}\right)\end{array}$ & 10 & $-9.06 \pm 0.27$ & 14.20 & 0 & N.D. & N.D. \\
\hline \multirow{2}{*}{$\begin{array}{l}\text { Strong } \\
\text { Face }\end{array}$} & $\mathrm{K} 45 \mathrm{D}$ & 4 & $-6.68 \pm 0.65$ & 3425.96 & 2 & $-9.21 \pm 0.49$ & 10.04 \\
\hline & $\mathrm{R} 150 \mathrm{~A}$ & 8 & $-8.14 \pm 0.06$ & 119.32 & 9 & $-10.41 \pm 0.29$ & 0.64 \\
\hline \multirow{9}{*}{$\begin{array}{l}\text { Weak } \\
\text { Face }\end{array}$} & S104I & 2 & N.A. & N.A. & 2 & N.D. & N.D. \\
\hline & R14E & 1 & N.A. & N.A. & 3 & N.A. & N.A. \\
\hline & $\mathrm{R} 14 \mathrm{Q}$ & 1 & N.A. & N.A. & 2 & N.A. & N.A. \\
\hline & $\mathrm{R} 14 \mathrm{~N}$ & 1 & N.A. & N.A. & 2 & N.A. & N.A. \\
\hline & Y15I & 2 & N.A. & N.A. & 2 & N.A. & N.A. \\
\hline & R103I & 1 & N.A. & N.A. & 3 & N.A. & N.A. \\
\hline & $\mathrm{R} 103 \mathrm{Q}$ & 2 & N.A. & N.A. & 3 & N.A. & N.A. \\
\hline & R103K & 6 & $-9.93 \pm 0.40$ & 1.94 & 8 & $-13.16 \pm 1.74$ & $1.14 \times 10^{-3}$ \\
\hline & L108A & 5 & N.A. & N.A. & 5 & $-13.74 \pm 1.54$ & $2.99 \times 10^{-4}$ \\
\hline
\end{tabular}

152 proliferation assays. TF-1 is an immature erythroid cell line that expresses both EPOR and GPA (1620 \pm

153140 and $3860 \pm 780$ molecules per cell, respectively) (Taylor et al., 2010), and requires EPO, GM-CSF, or

154 IL-3 for growth (Kitamura et al., 1989). TF-1 cells were starved of cytokines overnight and then exposed

155 to EPO variants for $72 \mathrm{hr}$. Their proliferation was measured by a standard tetrazolium-based assay. Wild- 
type EPO (epoetin alfa) and hyperglycosylated EPO (darbepoetin) exhibited $\mathrm{EC}_{50}$ values of $\sim 0.1 \mathrm{nM}$ and $\sim 1 \mathrm{nM}$, respectively. EPO mutations on the strong binding face reduced activity of unfused EPO by $\sim 120-$ to 3400 -fold relative to epoetin alfa. When these mutants were fused to $\mathrm{IH} 4$, their activities were rescued by $\sim 180$ - to 340 -fold relative to unfused mutants, showing comparable activity to epoetin alfa and darbepoetin (Table II and Fig. S1). The unfused EPOs with mutations on the weak face showed no activity at concentrations ranging from $10^{-14}$ to $10^{-7} \mathrm{M}$, except for $\operatorname{EPO}(\mathrm{R} 103 \mathrm{~K})$, which had a slightly lower $E_{50}$ value compared to epoetin alfa and approximately two-fold lower efficacy $\left(E_{\max }\right)$ (Table II and Fig. S1). When $E P O(R 103 K)$ was fused to $\mathrm{IH} 4$, the fusion protein exhibited significantly enhanced activity, with its $\mathrm{EC}_{50}$ value in a low femtomolar range. Among the weak-face mutants that completely lacked erythropoietic activity, only IH4-EPO(L108A) exhibited targeted erythropoietic activity, while the others remained inactive even after fusion. Similar to IH4-EPO(R103K), IH4-EPO(L108A) also had an $\mathrm{EC}_{50}$ of $\sim 1-10 \mathrm{fM}$ (Table II and Fig. 2A).
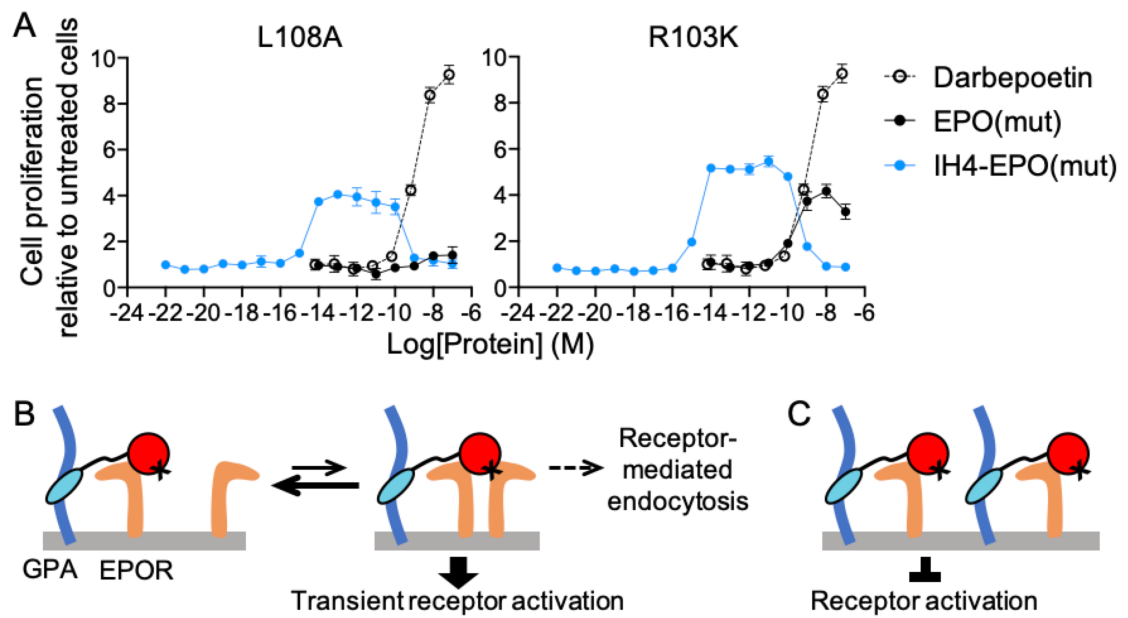

Fig. 2. Receptor activation by IH4-EPO(L108A or R103K) in TF-1 cells follows a bell-shaped dose response curve. (A) IH4-EPO(L108A or R103K) was tested for stimulation of proliferation of TF-1 cells, which express both EPOR and GPA (Taylor et al., 2010). The fusion proteins show extremely high potency, with $\mathrm{EC}_{50}$ values at a low femtomolar range, and a drop in bioactivity at high concentrations. Data represent mean \pm S.E.M. of three replicates. $(B, C)$ Schematic of proposed mechanisms for the bellshaped dose response curve. The fusion protein binds to GPA (dark blue) and one copy of EPOR (orange) via IH4 (light blue) and the strong face of EPO (red), respectively. (B) At low fusion protein concentrations, EPO has a brief interaction with the second copy of EPOR via the EPO weak face. This transient interaction activates EPOR signaling for cell proliferation, but does not last long enough to trigger receptor-mediated endocytosis. Thus, signaling does not terminate and a few signaling complexes per cell are sufficient to stimulate proliferation. (C) At high concentrations, fusion proteins saturate EPORs with a 1:1 stoichiometry via the strong-face interaction, resulting in a low number of complete signaling complexes composed of one ligand and two receptors.

The dose-response curve of weak-face mutants fused to IH4 showed two unusual features. First,

169 when $\mathrm{EPO}(\mathrm{L} 108 \mathrm{~A}$ or $\mathrm{R} 103 \mathrm{~K})$ is fused to $\mathrm{IH} 4$, the potency of the fusion protein is enhanced by four to five 170 orders of magnitude relative to wild-type EPO and other EPO fusion proteins. The $\mathrm{EC}_{50}$ is $\sim 1-10 \mathrm{fM}$ (Fig.

171 2A). Secondly, the dose-response curve of IH4-EPO(L108A or R103K) is bell-shaped, with stimulation

172 falling off at $\sim 1 \mathrm{nM}$, whereas fusion proteins containing strong-face mutants (K45D and R150A) show 
standard sigmoidal dose-response curves (Fig. 2A and Fig. S1). We speculate that these features result from distinct receptor binding properties of weak-face mutants. These mutations further reduce EPOEPOR interaction at the weak face, resulting in an extremely rapid off-rate. At low concentrations of the fusion protein, the binding of EPOR to EPO's weak face, needed for the formation of a complete signaling complex, may be so transient that the fusion protein activates EPORs for cell proliferation but cannot stay long enough to be endocytosed. This has the net effect of increasing the frequency of EPOR activation with a limited amount of the fusion protein (Fig. 2B). At high concentrations, the fusion protein saturates EPORs in a non-signaling, monomeric form via the strong side, and blocks receptor activation (Fig. 2C).
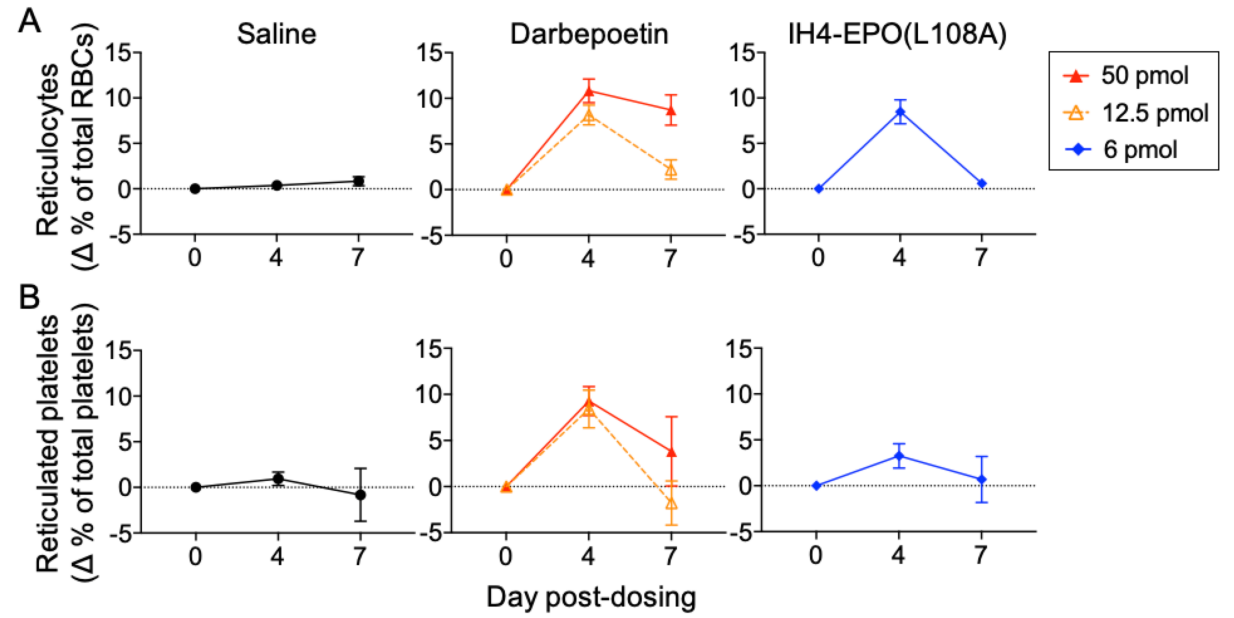

Fig. 3. Erythropoietic activity of IH4-EPO(L108A) in vivo. Transgenic mice that express human GPA on their RBCs received a single i.p. injection of saline, darbepoetin or IH4-EPO(L108A). Their reticulocyte and reticulated platelet levels were measured by flow cytometry on Days 0,4 and 7 post-injection. (A,B) While untargeted form, darbepoetin, stimulates the production of both reticulocytes and reticulated platelets, IH4-EPO(L108A) specifically stimulates RBC production and not platelet production in these mice. Data represent mean \pm S.E.M of five mice per dose group.

\section{Targeted erythropoietic activity of EPO-H in mice}

One of the fusion proteins, IH4-EPO(L108A), was tested for targeted erythropoietic activity in transgenic mice expressing human GPA. IH4-EPO(L108A) was chosen because EPO(L108A) by itself showed essentially no homodimeric EPOR activation in TF-1 cell proliferation assay, suggesting that potential pro-thrombotic side effects would be greatly reduced. Mice received a single intraperitoneal (i.p.) injection of saline, darbepoetin $(50 \mathrm{pmol}=2 \mu \mathrm{g} ; 12.5 \mathrm{pmol}=0.5 \mu \mathrm{g})$ or IH4-EPO(L108A) $(6 \mathrm{pmol}=0.3$ $\mu \mathrm{g})$. Target cell specificity and drug efficacy were measured by staining for reticulocytes and reticulated platelets in blood samples on Days 0, 4 and 7 post-injection. Reticulocyte and reticulated platelet levels remained at baseline (Day 0 ) throughout the experiment in the saline-treated mice, but increased significantly in mice treated with darbepoetin, a control for the untargeted form of EPO. Mice treated with $\mathrm{IH} 4-\mathrm{EPO}(\mathrm{L} 108 \mathrm{~A})$ had elevated reticulocyte counts $(8.47 \%)$ that were comparable to those in mice treated 
194 with $12.5 \mathrm{pmol}$ of darbepoetin (8.17\%) on Day 4 (Fig. 3A), but did not have significantly increased reticulated platelet counts (Fig. 3B). When various doses were tested $(40 \mathrm{pmol}=2 \mu \mathrm{g} ; 6 \mathrm{pmol}=0.3 \mu \mathrm{g}$; $1.2 \mathrm{pmol}=0.06 \mu \mathrm{g} ; 0.2 \mathrm{pmol}=0.01 \mu \mathrm{g}), \mathrm{IH} 4-\mathrm{EPO}(\mathrm{L} 108 \mathrm{~A})$ induced reticulocyte responses in a dosedependent manner: 40 pmol and 6 pmol resulted in $8.13 \%$ and $3.16 \%$ increases in reticulocyte counts on Day 4 relative to Day 0, respectively, while lower doses $(1.2 \mathrm{pmol}$ and $0.2 \mathrm{pmol})$ did not have significant effects (Fig. S2).

\section{Tissue-protective activity of EPO variants in vitro}

EPO mutants that displayed targeted erythropoietic activity were further evaluated to confirm their expected tissue-protective effects in cell-based assays. The ability of a fusion protein to protect cells was measured in vitro by estimating the number of surviving cells after treatment with EPO and a cobalt chloride $\left(\mathrm{CoCl}_{2}\right)$, which induces a hypoxia response via hypoxia-inducible factor-alpha (HIF-1 $\left.\alpha\right)$ due to its inhibition of prolyl hydroxylase (Epstein et al., 2001; Vengellur and LaPres, 2004; Yuan et al., 2003). SHSY5Y, a neuroblastoma cell line that expresses both EPOR and CD131 (Chamorro et al., 2013), was cotreated with engineered EPO variants and $100 \mu \mathrm{M}$ of $\mathrm{CoCl}_{2}$. Viable cells were measured $24 \mathrm{hr}$ later by standard tetrazolium dye-based assays. The optimal cell density and concentration of $\mathrm{CoCl}_{2}$ were chosen to cause $\sim 30-40 \%$ cell viability in the absence of EPO.

The control proteins, wild-type EPO (EPO(WT)) and EPO(S104I), protect neuroblastoma cells

212 from $\mathrm{CoCl}_{2}$ insult, although $\mathrm{EPO}(\mathrm{S} 104 \mathrm{I})$ had a much weaker effect than the wild-type (Fig. 4A, B and Fig.

213 S3). This is consistent with the previous results that EPO(WT) and EPO(S104I) protected primary

214 neurons from N-methyl-D-aspartic acid (NMDA)-induced excitotoxicity (Gan et al., 2012). While a fusion

215 protein containing a strong-face mutant, IH4-EPO(K45D), did not protect cells from $\mathrm{CoCl}_{2}$-induced cell

216 death (Fig. 4C and Fig. S3), fusion proteins containing a weak-face mutant, IH4-EPO(R103K) and IH4-

217 EPO(L108A), exhibited neuroprotective effects (Fig. 4D, E and Fig. S3). Similarly, a weak-face mutant,

$218 \mathrm{EPO}(\mathrm{L} 108 \mathrm{~A})$, also showed neuroprotective effect against $\mathrm{CoCl}_{2}$-induced hypoxic damage in the absence

219 of fusion to the IH4 nanobody (Fig. 4F and Fig. S3). Four-parameter fits of these data did not give

220 accurate $\mathrm{EC}_{50}$ values because the readouts did not reach saturation within the measured concentration

221 range. Despite this caveat, four-parameter fits provided rough estimates for the potency of each variant.

222 The $\mathrm{EC}_{50}$ values of EPO(WT) and EPO(S104I) were $1-5 \mathrm{nM}$. The $\mathrm{EC}_{50}$ values of IH4-EPO(R103K), IH4-

$223 \mathrm{EPO}(\mathrm{L} 108 \mathrm{~A})$ and $\mathrm{EPO}(\mathrm{L} 108 \mathrm{~A})$ were estimated to be $\sim 10-20 \mathrm{nM}$ (Fig. 4G).

$224 \quad$ Although the dynamic range and the four-parameter fits varied between independent

225 experiments, these EPO variants showed reproducible effects when they were repeated several times

226 and even when they were tested under different experimental conditions (Fig. S3-S5). When SH-SY5Y

227 cells were pre-exposed to EPO variants $24 \mathrm{hr}$ before receiving $100 \mu \mathrm{M}$ of $\mathrm{CoCl}_{2}, \mathrm{EPO}(\mathrm{L} 108 \mathrm{~A}$ or R103K)

228 in both unfused and fused forms protected cells from hypoxia-induced cell death (Fig. S4). 


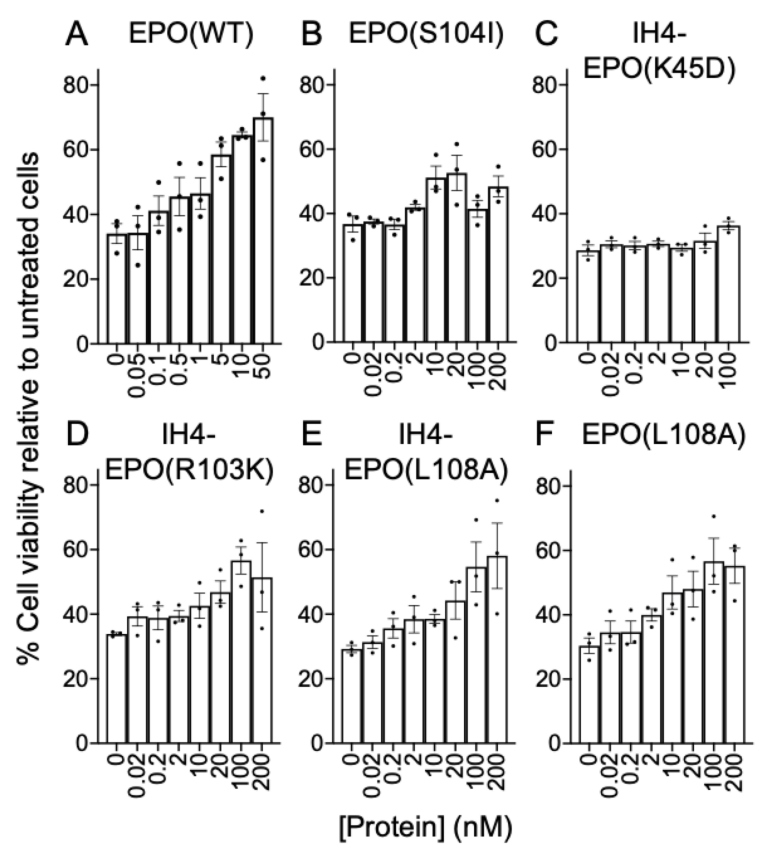

\begin{tabular}{|c|c|c|c|}
\hline & Protein & N & EC $_{50} \pm$ S.D. (nM) \\
\hline \multirow{3}{*}{ Control } & $\mathrm{EPO}(\mathrm{WT})$ & 8 & $3.77 \pm 4.70$ \\
\cline { 2 - 4 } & $\mathrm{EPO}(\mathrm{S} 104 \mathrm{I})$ & 2 & $1.22 \pm 1.19$ \\
\hline Strong Face & $\mathrm{IH} 4-\mathrm{EPO}(\mathrm{K} 45 \mathrm{D})$ & 3 & N.A. \\
\hline \multirow{3}{*}{ Weak Face } & $\mathrm{IH} 4-\mathrm{EPO}(\mathrm{R} 103 \mathrm{~K})$ & 3 & $9.65 \pm 6.61$ \\
\cline { 2 - 4 } & $\mathrm{IH} 4-\mathrm{EPO}(\mathrm{L} 108 \mathrm{~A})$ & 4 & $18.42 \pm 12.20$ \\
\cline { 2 - 4 } & $\mathrm{EPO}(\mathrm{L} 108 \mathrm{~A})$ & 2 & $18.88 \pm 7.66$ \\
\hline
\end{tabular}

Fig. 4. Ability of EPO variants to protect neuronal cells from $\mathrm{CoCl}_{2}$-induced hypoxic damage in vitro. $\mathrm{SH}$ SY5Y cells were co-treated with EPO and $\mathrm{CoCl}_{2}$ for $24 \mathrm{hr}$ and cell viability was measured. (A,B) Positive controls, EPO(WT) and EPO(S104I), protect neuronal cells from cell death in a dose-dependent manner, but (C) fusion protein containing a strong-face mutant, IH4-EPO(K45D), does not promote neuroprotection. (D-F) EPO variants containing a weak-face mutation, EPO(L108A) and IH4-EPO(L108A or R103K), also show neuroprotective effect against $\mathrm{CoCl}_{2}$-induced hypoxic damage. Data represent mean \pm S.E.M. of three replicates. (G) A summary of tissue-protective activity of EPO variants. $N$ indicates the number of repeat experiments, each containing two to four replicates. $E_{50}$ values were estimated by the standard four-parameter non-linear fit. See Supplementary Information for more details.

\section{Discussion}

231 In this work, we constructed an EPO fusion protein that can provide both erythropoietic and tissue-protective effects without causing thrombotic side effects. This novel molecule is designed to

233 prevent or treat hypoxia-mediated damage in patients suffering from illnesses, such as COPD and right-

234 side heart failure, to prevent altitude sickness in military personnel acclimating to high altitude regions and 235 possibly to enhance physical performance. It may also alleviate organ damage caused by hypoxia in

236 COVID-19 patients at risk of requiring a ventilator. However, achieving a safe and tissue-protective dose

237 of EPO is a challenge: the maximum allowed dose in patients with chronic kidney disease is limited by its 238 pro-thrombotic effects (Nichol et al., 2015), and the dose of EPO required for tissue-protective effects is at 
least as high or higher than for erythropoiesis (Masuda et al., 1994). If doses are limited to non-thrombotic "safe" levels, then EPO is likely to fail in clinical trials for tissue protection because such doses are below what is effective for tissue protection and not necessarily because the drug itself is not effective. By using the chimeric activator design, we addressed two major challenges in using EPO activity for the treatment of hypoxia - retaining both the erythropoietic activity and tissue-protective functions of EPO while reducing or eliminating its pro-thrombotic activity.

Previously described EPO derivatives lack the desired features for treatment of hypoxia. Darbepoetin simply extends the plasma half-life but has the same activities as EPO itself (Egrie and Browne, 2001; Egrie et al., 2003). Carbamylated EPO (Leist et al., 2004) and weak-face EPO mutants (such as EPO(S104I) (Gan et al., 2012)) retain neuroprotective activity but completely lack erythropoietic and pro-thrombotic activity. Targeted EPO molecules that we have constructed (Burrill et al., 2016; Lee et al., 2020) retain erythropoietic activity and are not pro-thrombotic, but are predicted to lack tissueprotective activity because they contain a mutation in the surface of EPO that strongly binds to EPOR; this surface is predicted to be critical for binding to EPOR-CD131 heterodimers that mediate tissue protection.

We therefore designed new EPO derivatives by combining two features: (1) a mutation on the surface of EPO that interacts weakly with EPOR, since such mutant EPOs retain tissue-protective activity and (2) an antibody-based GPA-binding element that should rescue activity on RBC precursors. This design mimics our previous Targeted EPO, except that the EPO mutation is in the weak face instead of the strong face with respect to interaction with EPOR. We found that most mutations in the weak face (specifically R14E, R14Q, R14N, Y15I, R103I and R103Q) abolished erythropoietic activity in cell-based proliferation assays, and the mutation R103K caused only a slight reduction in this assay. In contrast, EPO containing the mutation L108A completely lacked in vitro erythropoietic activity, but this activity was rescued when the mutant protein was fused to the GPA-targeting nanobody IH4 (Table II, Fig. 2A and Fig. S1). In addition, this fusion protein retained erythropoietic activity in vivo (Fig. 3 and Fig. S2), with a potency similar to our Targeted EPO and EPO itself (Burrill et al., 2016; Lee et al., 2020). Finally, the IH4$\mathrm{EPO}(\mathrm{L} 108 \mathrm{~A})$ fusion protein still showed neuroprotective activity in vitro in an assay in which neuroblastoma cells were treated with $\mathrm{CoCl}_{2}$, which induces a hypoxia response (Fig. 4, Fig. S3 and Fig. S4). Thus, the fusion protein $\mathrm{IH} 4-\mathrm{EPO}(\mathrm{L} 108 \mathrm{~A})$ is a potential candidate for treatment of hypoxia.

In in vitro testing for erythropoietic activity, the IH4-EPO(L108A) and IH4-EPO(R103K) fusion proteins showed two unusual properties: (1) extreme potency, with activity detectable at $\sim 1-10 \mathrm{fM}$ concentrations, and (2) loss of activity at $\sim 1 \mathrm{nM}$ concentration (Fig. 2A). These observations were made based on TF-1 erythroleukemia cell proliferation assays, in which cells were stimulated by wild-type EPO and engineered proteins. These effects are likely not relevant in vivo, since IH4-EPO(L108A) stimulates erythropoiesis at doses similar to EPO itself and does not show signs of extreme potency or autoinhibition (Fig. 3 and Fig. S2). Nonetheless, it may be useful to have a working model of these observations, as such an understanding may inform the engineering of other targeted proteins. 
We propose two mechanisms that could, in combination, explain the extremely high potency of $\mathrm{IH} 4-\mathrm{EPO}(\mathrm{L} 108 \mathrm{~A}$ or R103K). First, the attachment of the fusion protein to GPA could prevent receptormediated endocytosis and degradation of the signaling protein. In differentiating erythroleukemic cells, GPA is attached to a stable actin cytoskeleton that may preclude internalization. In non-differentiating erythroleukemic cells, GPA is internalized by a clathrin-mediated pathway but at a much slower rate compared to other membrane proteins (Marshall et al., 1984; Ktistakis et al., 1990). Therefore, binding to GPA may interfere with internalization and degradation of the fusion protein. However, simple attachment of an EPO fusion protein to GPA does not profoundly enhance its potency, since we do not observe highly potent activity with other anti-GPA/EPO fusion proteins. Second, we propose that the fusion protein may form a highly stable complex with GPA and one copy of EPOR via the strongly interacting side of EPO, but interaction with the second EPOR to form a complete signaling complex may be weak and dissociate rapidly due to a mutation. The interaction may last long enough to phosphorylate a subset of the tyrosine residues important in signal transduction into the nucleus but may not be long enough to phosphorylate residues involved in signaling to the clathrin system for receptor-mediated endocytosis (Fig. 2B). In these assays, stimulation of proliferation is observed with as few as six to sixty molecules of fusion protein per cell, suggesting that this is the minimum number of molecules needed to promote erythropoietic signaling (see Supplementary Information for a quantitative explanation).

The loss of activity by IH4-EPO(L108A or R103K) at >1 nM concentrations can be explained by receptor saturation that has been observed in other systems that require more than two receptors for signaling (Fuh et al., 1992; Atanasova and Whitty, 2012; Kallenberger et al., 2014). Similar to EPO, human growth hormone ( $\mathrm{hGH}$ ) asymmetrically binds to two hGH receptors to trigger signaling. Fuh et al. (1992) showed that wild-type hGH inhibits signaling at $>2 \mu \mathrm{M}$, and mutation of the weak-binding face of $\mathrm{hGH}$ further reduces the $\mathrm{IC}_{50}$ value to $\sim 100 \mathrm{nM}$. They also demonstrated that the antagonistic behaviors resulted from the disruption of receptor dimerization, using divalent monoclonal antibodies for hGH receptors (Fuh et al., 1992). Similarly, our fusion protein containing a weak-face EPO mutation may saturate monomeric EPOR in a 1:1 stoichiometry and block the formation of a complete signaling complex consisting of homodimeric EPOR, resulting in auto-inhibition of EPO signaling (Fig. 2C).

It is important to note that while we observe an enhanced potency of $\mathrm{IH} 4-\mathrm{EPO}(\mathrm{L} 108 \mathrm{~A})$ in the cell based assay, in our in vivo erythropoiesis experiments the potency of this molecule was similar to that of darbepoetin and EPO fusion proteins that we constructed previously. In the in vitro assay, there may be essentially no removal of the fusion protein, while in vivo the normal clearance mechanisms would likely still operate, such as pinocytosis and degradation by Kupffer cells and/or binding to EPORs on nonerythroid cells and removal by non-signaling receptor-mediated endocytosis (Wiley, 2003).

Taken together, our results indicate that IH4-EPO(L108A) could be an ideal molecule for

310 treatment of hypoxia. The fusion protein is expected to enhance oxygen delivery and prevent hypoxia-

311 induced cell death, without causing thrombosis. This work demonstrates that our engineering strategies

312 allow for selective utilization of beneficial EPO activities and inhibition of undesired effects. More broadly, 
313 it further solidifies the value of the "chimeric activator" approach in designing targeted protein

314 therapeutics.

316 Methods

317 Cell culture

318 FreeStyle 293-F and FreeStyle CHO-S cell lines were obtained from Invitrogen (Carlsbad, CA) and

319 cultured in FreeStyle 293 Expression Medium and complete FreeStyle CHO Expression Medium

320 (Invitrogen), respectively. Human erythroleukemia TF-1 and human neuroblastoma SH-SY5Y were

321 obtained by ATCC (Manassas, VA). TF-1 was cultured in RPMI-1640 with 10\% FBS, $100 \mathrm{U} / \mathrm{mL}$ penicillin,

$322100 \mathrm{U} / \mathrm{mL}$ streptomycin, and $2 \mathrm{ng} / \mathrm{mL}$ recombinant human granulocyte macrophage colony-stimulating

323 factor (GM-CSF; PeproTech) unless specified otherwise. SH-SY5Y was cultured in 1:1 DMEM/F-12 with

$32410 \%$ FBS. 293-F and $\mathrm{CHO}-\mathrm{S}$ were cultured at $37^{\circ} \mathrm{C}$ in $8 \% \mathrm{CO}_{2}$ with shaking at $2.35 \times \mathrm{g}$. TF-1 and SH-

325 SY $5 Y$ were cultured at $37^{\circ} \mathrm{C}$ in $5 \% \mathrm{CO}_{2}$.

\section{DNA constructs}

328 The DNA sequence for EPO wild-type was from GenBank (accession no. KX026660). EPO mutant

329 sequences were constructed by introducing a codon change into the wild-type sequence. The DNA

330 sequence for the $\mathrm{IH} 4$ nanobody was derived by reverse translating and codon optimizing (Integrated DNA

331 Technologies) the protein sequence adapted from the US patent 9879090 (Bertrand et al., 2018). It was

332 modified to include a point mutation (Phe80Tyr) in the framework region 3 to reflect the consensus of the

333 germline sequences, and an additional amino acid (Thr118) in the framework region 4, as the reported

334 sequence had a typographical error. See Supplementary Information for individual sequences.

Protein expression and purification

337 Transient expression was performed in 293-F and CHO-S cells using pSecTag2A or pOptiVEC plasmids

338 according to the supplier's protocol. 4-6 days after transfection, protein expression was assayed by

339 Western blotting cell supernatant using anti-6xHis-HRP antibody (Abcam). Proteins from transient

340 transfection were purified as follows. Supernatant was concentrated to 5-8 mL using a $10 \mathrm{kDa}$ cut-off

341 Macrosep Advance centrifugal device (Pall). Concentrated protein was bound to $0.5-1 \mathrm{~mL}$ of His60 nickel

342 or HisTalon cobalt resin (Takara Bio) for $0.5-1 \mathrm{hr}$ at $4^{\circ} \mathrm{C}$ while rotating in a $10-\mathrm{mL}$ Pierce disposable

343 column (Thermo Scientific), and was washed and eluted using His60 or HisTalon Buffer Set (Takara Bio)

344 according to the supplier's protocol. Cell supernatant and each purification fraction were analyzed by

345 SDS-PAGE followed by Coomassie Blue staining. Eluted proteins were combined, desalted into

346 endotoxin-free PBS (Teknova: $137 \mathrm{mM} \mathrm{NaCl}, 1.4 \mathrm{mM} \mathrm{KH}_{2} \mathrm{PO}_{4}, 4.3 \mathrm{mM} \mathrm{Na}_{2} \mathrm{HPO}_{4}$, and $2.7 \mathrm{mM} \mathrm{KCl}, \mathrm{pH}$

347 7.4) using Econo-Pac 10DG columns (Bio-Rad), and concentrated to $<1 \mathrm{~mL}$ using Macrosep Advance

348 centrifugal device. 
For in vivo experiments, contaminating proteins were further removed by anion-exchange chromatography (AIEX) on HiPrep DEAE FF 16/10, followed by size exclusion chromatography (SEC) on Superdex 200 10/300 GL columns (Cytiva), using AKTA FPLC system (Cytiva). For AIEX, 1 M Tris-HCl, $\mathrm{pH} 8.0$ was used as the starting buffer and a linear gradient up to $1 \mathrm{M} \mathrm{NaCl}$ was used for elution. For SEC, endotoxin-free PBS was used as the running buffer. Desired protein fractions were combined and concentrated to $<1 \mathrm{~mL}$ using Macrosep Advance centrifugal device. Proteins were stored at $4^{\circ} \mathrm{C}$ throughout the described process, ultimately stored as aliquots at $-80^{\circ} \mathrm{C}$, and thawed once before use. Only endotoxin-free reagents were used.

\section{TF-1 cell proliferation assays}

359 TF-1 cells were seeded in a 96 -well plate at $9.0 \times 10^{3}$ cells per well in $90 \mu \mathrm{L}$ of RPMI- 1640 with serum and 360 antibiotics (no GM-CSF). The purified proteins were serially diluted by 10 -fold $\left(10^{-7}\right.$ to $10^{-14}$ or $10^{-21} \mathrm{M}$ ) or 361100 -fold $\left(10^{-7}\right.$ to $\left.10^{-21} \mathrm{M}\right)$ and added to the cells. Cells were incubated at $37^{\circ} \mathrm{C}$ in $5 \% \mathrm{CO}_{2}$ for $72 \mathrm{hr}$. Cell 362 proliferation was determined by CellTiter $96^{\circledR}$ AQueous One Solution Cell Proliferation Assay (Promega) 363 or adding $10 \mu \mathrm{L}$ of WST-1 reagent (Roche). 2-4 hr after adding the reagent, absorbance at $490 \mathrm{~nm}$ (and 364 background absorbance at $650 \mathrm{~nm}$ when using WST-1) was read on a BioTek Synergy Neo HTS microplate reader. Reported data represent mean \pm SEM of three replicates.

\section{Measuring mouse reticulocytes and reticulated platelets}

368 Human GPA-transgenic FVB mice were generously donated by the Hendrickson Laboratory at Yale

369 University (Auffray et al., 2001). This strain underwent embryo re-derivation at Charles River

370 Laboratories. The homozygous human GPA transgene is embryonic-lethal but heterozygotes are

371 phenotypically normal, so a breeding colony was maintained with screening for human GPA at each

372 generation. Transgene expression was measured as described before (Burrill et al., 2016).

Five mice per dose group received a single intraperitoneal (i.p.) injection with saline, darbepoetin or EPO fusion protein in a $200 \mu \mathrm{L}$ volume (diluted in saline or PBS) on Day $0.1-5 \mu \mathrm{L}$ of whole blood was collected by tail-nick in EDTA-coated tubes on Days 0, 4 and 7 post-injection. Blood was analyzed immediately after collection by flow cytometry as described before (Burrill et al., 2016). Briefly, thiazole orange (Sigma-Aldrich) was used to stain residual RNA in reticulocytes and reticulated platelets, and antiCD41-PE antibody (BD Pharmingen) was used to stain total platelets. A stock solution $(1 \mathrm{mg} / \mathrm{mL})$ of thiazole orange was prepared in $100 \%$ methanol and was diluted 1:5,000 in PBS to make a 2x working solution. Anti-CD41-PE antibody was diluted 1:500 in either the $2 x$ working solution of thiazole orange for

381 stained samples or PBS for gating thiazole orange-negative population. Whole blood was diluted 1:1,000

382 in PBS. Equal volumes $(100 \mu \mathrm{L})$ of $2 x$ working solution of anti-CD41-PE antibody with or without thiazole 383 orange and diluted whole blood were mixed in a 96-well U-bottom plate and incubated for 30 min in the 384 dark at $23^{\circ} \mathrm{C}$. The fluorescence was measured on a LSRFortessa SORP flow cytometer equipped with 
an optional HTS sampler (BD Biosciences) using the following filter configuration: PE excitation, 561/50 $\mathrm{mW}$; emission filter, BP 582/15; YFP excitation, 488/100 mW; emission filter, BP 540/25.

\section{Tissue protection assay}

SH-SY5Y cells were seeded in a 96-well plate at $4.8 \times 10^{4}$ cells per well in $80 \mu \mathrm{L}$ of 1:1 DMEM/F-12 with $10 \% \mathrm{FBS}$, and let adhere overnight at $37^{\circ} \mathrm{C}$ in $5 \% \mathrm{CO}_{2}$. In co-treatment experiments, cells received varying concentrations of purified proteins $(0.02$ to $200 \mathrm{nM})$ and $100 \mu \mathrm{M}$ of cobalt chloride $\left(\mathrm{CoCl}_{2}\right)$, a hypoxia mimicking agent, and were incubated at $37^{\circ} \mathrm{C}$ in $5 \% \mathrm{CO}_{2}$ for $24 \mathrm{hr}$. In pre-treatment experiments (Fig. S4), cells were treated with purified proteins $24 \mathrm{hr}$ before receiving $\mathrm{CoCl}_{2}$ and were incubated at $37^{\circ} \mathrm{C}$ in $5 \% \mathrm{CO}_{2}$ for additional $24 \mathrm{hr}$ after adding $\mathrm{CoCl}_{2}$. Cell viability was measured by CellTiter $96 \AA$ $\mathrm{AQ}_{\text {ueous }}$ One Solution Cell Proliferation Assay (Promega). 2-4 hr after adding the reagent, absorbance at $490 \mathrm{~nm}$ was read on a BioTek Synergy Neo HTS microplate reader. In experiments shown in Supplementary Figure 5, SH-SY5Y cells were seeded in a 96-well plate at $1.2 \times 10^{4}$ cells per well in $80 \mu \mathrm{L}$. On the next day, cells were co-treated with varying concentrations of purified proteins (0.02 to $200 \mathrm{nM})$ and 25 or $50 \mu \mathrm{M}$ of $\mathrm{CoCl}_{2}$, and incubated at $37^{\circ} \mathrm{C}$ in $5 \% \mathrm{CO}_{2}$ for $72 \mathrm{hr}$. Cell viability was measured by adding $10 \mu \mathrm{L}$ of WST-1 reagent (Roche). $4 \mathrm{hr}$ after adding the reagent, absorbance at $490 \mathrm{~nm}$ and 650 $\mathrm{nm}$ (background) was read on a BioTek Synergy Neo HTS microplate reader. Reported data represent mean \pm S.E.M of two to four replicates.

\section{Acknowledgements}

This work was supported by funds from the Wyss Institute for Biologically Inspired Engineering and the Boston Biomedical Innovation Center (Pilot Award 112475; Drive Award U54HL119145). J.L., K.M.K., D.R.B., J.C.W. and P.A.S. were supported by the Harvard Medical School Department of Systems Biology. J.C.W. was further supported by the Harvard Medical School Laboratory of Systems Pharmacology. A.V., D.R.B. and P.A.S. were further supported by the Wyss Institute for Biologically Inspired Engineering. N.G.G. was sponsored by the Army Research Office under Grant Number W911NF-17-2-0092. The views and conclusions contained in this document are those of the authors and should not be interpreted as representing the official policies, either expressed or implied, of the Army

413 Research Office or the U.S. Government. The U.S. Government is authorized to reproduce and distribute 414 reprints for Government purposes notwithstanding any copyright notation herein. We sincerely thank 415 Amanda Graveline and the Wyss Institute at Harvard for their scientific support.

\section{Author contributions}

418 J.L., K.M.K. and J.C.W. designed research; J.L., A.V., N.G.G., K.M.K. and J.C.W. performed research; 419 J.L., K.M.K., D.R.B. and J.C.W. analyzed data; and, J.L., D.R.B., J.C.W. and P.A.S. wrote the paper. 
bioRxiv preprint doi: https://doi.org/10.1101/2021.06.24.449789; this version posted June 24, 2021. The copyright holder for this preprint (which was not certified by peer review) is the author/funder, who has granted bioRxiv a license to display the preprint in perpetuity. It is made available under aCC-BY-NC-ND 4.0 International license.

\section{Conflict of Interest Statement}

423 J.C.W., D.R.B. and P.A.S. are shareholders in a company that has a license to the $\mathrm{IH} 4$ antibody element 424 described in this work.

425 


\section{References}

1. Aloizos, S., Evodia, E., Gourgiotis, S., Isaia, E.C., Seretis, C. and Baltopoulos, G.J. (2015) Turk Neurosurg, 25, 552-558.

2. Atanasova, M. and Whitty, A. (2012) Crit Rev Biochem Mol Biol, 47, 502-530.

3. Auffray, I., Marfatia, S., de Jong, K., Lee, G., Huang, C.H., Paszty, C., Tanner, M.J., Mohandas, N. and Chasis, J.A. (2001) Blood, 97, 2872-2878.

4. Bennis, Y., Sarlon-Bartoli, G., Guillet, B., Lucas, L., Pellegrini, L., Velly, L., Blot-Chabaud, M., Dignat-Georges, F., Sabatier, F. and Pisano P. (2012) J Thromb Haemost, 10, 1914-1928.

5. Bertrand, O., Habib, I. and Smolarek, D. (2018) US Patent Application No. 9,879,090.

6. Brines, M., Grasso, G., Fiordaliso, F., Sfacteria, A., Ghezzi, P., Fratelli, M., Latini, R., Xie, Q.W., Smart, J., Su-Rick, C.J., Pobre, E., Diaz, D., Gomez, D., Hand, C., Coleman, T. and Cerami, A. (2004) Proc Natl Acad Sci U S A, 101, 14907-14912.

7. Bunn, H.F. (2013) Cold Spring Harb Perspect Med, 3, a011619.

8. Burrill, D.R., Vernet, A., Collins, J.J., Silver, P.A. and Way J.C. (2016) Proc Natl Acad Sci U S A, 113, 5245-5250.

9. Chamorro, M.E., Wenker, S.D., Vota, D.M., Vittori, D.C. and Nesse AB. (2013) Biochim Biophys Acta, 1833, 1960-1968.

10. Drüeke, T.B., Locatelli, F., Clyne, N., Eckardt, K.U., Macdougall, I.C., Tsakiris, D., Burger, H.U., Scherhag, A. and CREATE Investigators. (2006) N Engl J Med, 355, 2071-2084.

11. Egrie, J.C. and Browne, J.K. (2001) Br J Cancer, 84 Suppl 1, 3-10.

12. Egrie, J.C., Dwyer, E., Browne, J.K., Hitz, A. and Lykos, M.A. (2003) Exp Hematol, 31, 290-299.

13. Ehrenreich, H., Fischer, B., Norra, C., Schellenberger, F., Stender, N., Stiefel, M., Sirén, A.L., Paulus, W., Nave, K.A., Gold, R. and Bartels, C. (2007) Brain, 130, 2577-2588.

14. Ehrenreich, H., Hasselblatt, M., Dembowski, C., Cepek, L., Lewczuk, P., Stiefel, M., Rustenbeck, H.H., Breiter, N., Jacob, S., Knerlich, F., Bohn, M., Poser, W., Rüther, E., Kochen, M., Gefeller, O., Gleiter, C., Wessel, T.C., De Ryck, M., Itri, L., Prange, H., Cerami, A., Brines, M. and Sirén, A.L. (2002) Mol Med, 8, 495-505.

15. Elliott, S., Lorenzini, T., Chang, D., Barzilay, J. and Delorme, E. (1997) Blood, 89, 493-502.

16. Elliott, S., Sinclair, A., Collins, H., Rice, L. and Jelkmann, W. (2014) Ann Hematol, 93, 181-192.

17. Epstein, A.C., Gleadle, J.M., McNeill, L.A., Hewitson, K.S., O'Rourke, J., Mole, D.R., Mukherji, M., Metzen, E., Wilson, M.I., Dhanda, A., Tian, Y.M., Masson, N., Hamilton, D.L., Jaakkola, P., Barstead, R., Hodgkin, J., Maxwell, P.H., Pugh, C.W., Schofield, C.J. and Ratcliffe, P.J. (2001) Cell, 107, 43-54.

18. Fantacci, M., Bianciardi, P., Caretti, A., Coleman, T.R., Cerami, A., Brines, M. and Samaja, M. (2006) Proc Natl Acad Sci U S A, 103, 17531-17536.

19. Fuh, G., Cunningham, B.C., Fukunaga, R., Nagata, S., Goeddel, D.V. and Wells, J.A. (1992) Science, 256, 1677-1680. 
20. Gan, Y., Xing, J., Jing, Z., Stetler, R.A., Zhang, F., Luo, Y., Ji, X., Gao, Y. and Cao, G. (2012) Stroke, 43, 3071-3077.

21. Ghezzi, P. and Brines, M. (2004) Cell Death Differ, 11, S37-S44.

22. Hanazono, Y., Sasaki, K., Nitta, H., Yazaki, Y. and Hirai, H. (1995) Biochem Biophys Res Commun, 208, 1060-1066.

23. Henke, M., Laszig, R., Rübe, C., Schäfer, U., Haase, K.D., Schilcher, B., Mose, S., Beer, K.T., Burger, U., Dougherty, C. and Frommhold, H. (2003) Lancet, 362, 1255-1260.

24. Hernández, C.C., Burgos, C.F., Gajardo, A.H., Silva-Grecchi, T., Gavilan, J., Toledo, J.R., Fuentealba, J. (2017) Neural Regen Res, 12, 1381-1389.

25. Kallenberger, S.M., Beaudouin, J., Claus, J., Fischer, C., Sorger, P.K., Legewie, S. and Eils, R. (2014) Sci Signal, 7, ra23.

26. Kitamura, T., Tange, T., Terasawa, T., Chiba, S., Kuwaki, T., Miyagawa, K., Piao, Y.F., Miyazono, K., Urabe, A. and Takaku, F. (1989) J Cell Physiol, 140, 323-334.

27. Kontos, S. and Hubbell, J.A. (2010) Mol Pharm, 7, 2141-2147.

28. Kontos, S., Kourtis, I.C., Dane, K.Y. and Hubbell, J.A. (2013) Proc Natl Acad Sci U S A, 110, E60-E68.

29. Ktistakis, N.T., Thomas, D. and Roth, M.G. (1990) J Cell Biol, 111, 1393-1407.

30. Lee, J., Vernet, A., Redfield, K., Lu, S., Ghiran, I.C., Way, J.C. and Silver, P.A. (2020) ACS Synth Biol, 9, 191-197.

31. Leist, M., Ghezzi, P., Grasso, G., Bianchi, R., Villa, P., Fratelli, M., Savino, C., Bianchi, M., Nielsen, J., Gerwien, J., Kallunki, P., Larsen, A.K., Helboe, L., Christensen, S., Pedersen, L.O., Nielsen, M., Torup, L., Sager, T., Sfacteria, A., Erbayraktar, S., Erbayraktar, Z., Gokmen, N., Yilmaz, O., Cerami-Hand, C., Xie, Q.W., Coleman, T., Cerami, A. and Brines, M. (2004) Science, 305, 239-242.

32. Marshall, L.M., Thureson-Klein, A. and Hunt, R.C. (1984) J Cell Biol, 98, 2055-2063.

33. Masuda, S., Okano, M., Yamagishi, K., Nagao, M., Ueda, M. and Sasaki, R. (1994) J Biol Chem, 269, 19488-19493.

34. Nichol, A., French, C., Little, L., Presneill, J., Cooper, D.J., Haddad, S., Duranteau, J., Huet, O., Skrifvars, M., Arabi, Y., Bellomo, R. and EPO-TBI Investigators and the Australian and New Zealand Intensive Care Society Clinical Trials Group. (2015) Trials. doi: 10.1186/s13063-0140528-6.

35. Ogunshola, O.O. and Bogdanova, A.Y. (2013) Methods Mol Biol, 982, $13-41$.

36. Okazaki, T., Ebihara, S., Asada, M., Yamanda, S., Niu, K. and Arai, H. (2008) Neoplasia, 10, 932-939.

37. Park, K.H., Choi, N.Y., Koh, S.H., Park, H.H., Kim, Y.S., Kim, M.J., Lee, S.J., Yu, H.J., Lee, K.Y., Lee, Y.J. and Kim, H.T. (2011) Neurotoxicology, 32, 879-887. 
38. Pfeffer, M.A., Burdmann, E.A., Chen, C.Y., Cooper, M.E., de Zeeuw, D., Eckardt, K.U., Feyzi, J.M., Ivanovich, P., Kewalramani, R., Levey, A.S., Lewis, E.F., McGill, J.B., McMurray, J.J., Parfrey, P., Parving, H.H., Remuzzi, G., Singh, A.K., Solomon, S.D., Toto, R. and TREAT Investigators. (2009) N Engl J Med, 361, 2019-2032.

39. Robinson, S., Winer, J.L., Chan, L.A.S., Oppong, A.Y., Yellowhair, T.R., Maxwell, J.R., Andrews, N., Yang, Y., Sillerud, L.O., Meehan, W.P. III, Mannix, R., Brigman, J.L. and Jantzie, L.L. (2018) Front Neurol. doi: 10.3389/fneur.2018.00451.

40. Singh, A.K., Szczech, L., Tang, K.L., Barnhart, H., Sapp, S., Wolfson, M., Reddan, D. and CHOIR Investigators. (2006) N Engl J Med, 355, 2085-2098.

41. Syed, R.S., Reid, S.W., Li, C., Cheetham, J.C., Aoki, K.H., Liu, B., Zhan, H., Osslund, T.D., Chirino, A.J., Zhang, J., Finer-Moore, J., Elliott, S., Sitney, K., Katz, B.A., Matthews, D.J., Wendoloski, J.J., Egrie, J. and Stroud, R.M. (1998) Nature, 395, 511-516.

43. Vengellur, A. and LaPres, J.J. (2004) Toxicol Sci, 82, 638-646.

44. Wiley, H.S. (2003) Exp Cell Res, 284, 78-88.

45. Yasuda, Y., Fujita, Y., Matsuo, T., Koinuma, S., Hara, S., Tazaki, A., Onozaki, M., Hashimoto, M., Musha, T., Ogawa, K., Fujita, H., Nakamura, Y., Shiozaki, H. and Utsumi, H. (2003) Carcinogenesis, 24, 1021-1029. 